\title{
Organic carbon dynamics in interrows of Vitis vinifera with different years of soil use
}

\section{and management}

Dinâmica do carbono orgânico em entrelinhas de Vitis vinifera com diferentes anos de uso e manejo

do solo

\section{Dinámica del carbono orgánico en las interrelaciones de Vitis vinifera con diferentes años de uso y manejo del suelo}

Caroline Valverde dos Santos

ORCID: https://orcid.org/0000-0001-9432-4804 Universidade Estadual do Sudoeste da Bahia, Brazil E-mail: caroline.valverde@uesb.edu.br

Renato Levien

ORCID: https://orcid.org/0000-0002-3274-0228 Universidade Federal do Rio Grande do Sul, Brazil E-mail: renatole@ufrgs.br

Michael Mazurana

ORCID: https://orcid.org/0000-0003-4516-7659 Universidade Federal do Rio Grande do Sul, Brazil E-mail: michael.mazurana@gmail.com

Lucas Zulpo

ORCID: https://orcid.org/0000-0002-7964-5340 Universidade Federal do Rio Grande do Sul, Brazil E-mail: lucaszulpo@yahoo.com.br

\begin{abstract}
This study aimed to evaluate the effects of soil use and management on organic carbon stocks in the interrows of Vitis vinifera with different years of cultivation. A vineyard located in Rio Grande do Sul state, with 4, 9 and 16 years of management, was evaluated. Soil samples from different layers, 0.0-0.10, 0.10-0.20, 0.20-0.30, 0.30-0.40, 0.40-0.50 and $0.50-0.60 \mathrm{~m}$, were collected on wheel tracks, between wheel tracks and under the planting rows. As a reference, samples were collected in native grassland of the region. Organic matter content, bulk density and soil porosity were evaluated. Carbon stock was determined according to the correction of the sampled thickness. The results were subjected to analysis of variance and means were compared by Tukey test at 0.05 probability level. Soil management caused alterations in its structure and organic matter content, observed mainly in the first $30 \mathrm{~cm}$, regardless of the area studied. Highest values of bulk density were observed on the tractor wheel tracks, followed by under the planting row and between wheel tracks. Alteration in soil cover for vineyard planting led to a reduction in the carbon stock, compared to the native grassland. The area under management for 4 years showed higher carbon stocks between the wheel tracks, whereas the areas under 9 and 16 years of management showed highest values in the wheel tracks.
\end{abstract}

Keywords: Viticulture; Soil structure; Carbon stock.

\section{Resumo}

Este estudo teve como objetivo avaliar os efeitos do uso e manejo do solo sobre os estoques de carbono orgânico em entrelinhas de Vitis vinifera com diferentes anos de cultivo. Foi avaliada uma vinha localizada no estado do Rio Grande do Sul, com 4, 9 e 16 anos de manejo. Amostras de solo de diferentes camadas, 0,0-0,10, 0,10-0,20, 0,20-0,30, 0,30-0,40, 0,40-0,50 e 0,50-0,60 m, foram coletadas em pistas de roda, entre as pistas de roda e sob as linhas de plantio. Como referência, as amostras foram coletadas em pastagens nativas da região. Foram avaliados o teor de matéria orgânica, a densidade do solo e a porosidade do solo. O estoque de carbono foi determinado de acordo com a correção da espessura amostrada. Os resultados foram submetidos à análise de variância e as médias comparadas pelo teste de Tukey ao nível de probabilidade de 0,05. O manejo do solo ocasionou alterações em sua estrutura e teor de matéria orgânica, observadas principalmente nos primeiros $30 \mathrm{~cm}$, independente da área estudada. Os maiores valores de densidade do solo foram observados na esteira do trator, seguidos sob a linha de plantio e entre a esteira. A alteração da cobertura do solo para o plantio da vinha levou à redução do estoque de carbono, em comparação com a pastagem nativa. A área sob manejo há 4 anos apresentou maiores estoques de carbono entre os rodados, enquanto as áreas com menos de 9 e 16 anos de manejo apresentaram maiores valores nos rodados.

Palavras-chave: Viticultura; Estrutura do solo; Estoque de carbono. 


\begin{abstract}
Resumen
Este estudio tuvo como objetivo evaluar los efectos del uso y manejo del suelo sobre las existencias de carbono orgánico en las entrecruzadas de Vitis vinifera con diferentes años de cultivo. Se evaluó un viñedo ubicado en el estado de Rio Grande do Sul, con 4, 9 y 16 años de manejo. Se recolectaron muestras de suelo de diferentes capas, $0.0-0.10,0.10-0.20,0.20-0.30,0.30-0.40,0.40-0.50$ y $0.50-0.60 \mathrm{~m}$, en huellas de ruedas, entre huellas de ruedas y debajo de las hileras de siembra. Como referencia, se recolectaron muestras en pastizales nativos de la región. Se evaluó el contenido de materia orgánica, la densidad aparente y la porosidad del suelo. La reserva de carbono se determinó de acuerdo con la corrección del espesor muestreado. Los resultados se sometieron a análisis de varianza y las medias se compararon mediante la prueba de Tukey a un nivel de probabilidad de 0.05. El manejo del suelo provocó alteraciones en su estructura y contenido de materia orgánica, observadas principalmente en los primeros 30 $\mathrm{cm}$, independientemente del área estudiada. Los valores más altos de densidad aparente se observaron en las huellas de las ruedas del tractor, seguidas por debajo de la hilera de siembra y entre las huellas de las ruedas. La alteración de la cobertura del suelo para la plantación de viñedos condujo a una reducción de la reserva de carbono, en comparación con los pastizales nativos. El área bajo manejo durante 4 años mostró mayores reservas de carbono entre las huellas de las ruedas, mientras que las áreas bajo 9 y 16 años de manejo mostraron valores más altos en las huellas de las ruedas.

Palabras clave: Viticultura; Estructura del suelo; Reserva de carbono.
\end{abstract}

\title{
1. Introduction
}

Agricultural production has led to changes in soil quality, and soil structure is the factor directly related to such changes. Reduction in porosity and consequent increase in bulk density has caused a reduction in soil organic matter contents, contributing to the emission of gases, due to the release of CO2. According to Diekow et al. (2005) and Novais et al. (2007), the type of management adopted is a decisive condition in the alteration of soil carbon stocks and may result in the increase of these stocks in cultivated areas to values higher than those found in the same soil under native vegetation. Deforestation and vegetation burning, associated with the conventional soil tillage, with intense utilization of agricultural machinery, compromise soil properties and notably contribute to climate changes (Bernoux et al., 2005; Rangel \& Silva, 2007)

There is scientific consensus that terrestrial ecosystems are important for $\mathrm{C}$ cycle and that the soil is considered as its largest reservoir (Silva \& Medonça, 2007). According to Sleutel et al. (2006), C sequestration in the soil depends on factors such as vegetation cover, management practices and classes of soil.

Bayer and Mielniczuk (2008) consider that the following elements are among the abiotic factors are related to retention and/or accumulation of $\mathrm{C}$ in the soil: chemical management, climate, soil mechanics and soil capacity to protect organic matter (OM). Silva et al. (2006) point out that biotic compartments such as the edaphic fauna (micro, meso and macro) are important reservoirs of soil OM. Preservation and/or supply of plant material on soil surface, as well as the reduction in its turning, are strategies used to increase carbon storage in the soil, improving its quality, in addition to benefiting the environmental quality (Viana et al., 2016).

In the different land use systems, $\mathrm{C}$ is released by the vegetation after its cutting and burning and by the soil after the frequent tillage operations. On the other hand, the use of management practices can potentially mitigate and reduce $\mathrm{C}$ emissions, by sequestrating, capturing and maintaining it for as long as possible in the biomass, soil and oceans (Rosa-Filho et al., 2014). Alterations in land use, therefore, are closely related to organic matter dynamics and the biogeochemical cycle of the elements, modifying the production capacity of these environments (Brown et al., 1994). The content of organic carbon in the soil under different systems provides important information to assess soil quality.

Conversion of soil cover for the production of perennial crops causes alterations in soil quality, and organic carbon content is the most management-sensitive indicator. However, studies related to organic carbon dynamics in areas under perennial crops, especially observing the sites influenced by the traffic of tractor tracks, compared to sites not influenced, are scarce. In view of the above, this study aimed to evaluate the effects of use and management on organic carbon stocks in interrows of Vitis vinifera with different years of cultivation. 


\section{Methodology}

The study was carried out in a vineyard (Vitis vinifera, var. Pinot noir) situated in the municipality of Encruzilhada do Sul, at $30^{\circ} 31^{\prime} 37^{\prime \prime}$ South, $52^{\circ} 31^{\prime} 6^{\prime \prime}$ West of Greenwich and $348 \mathrm{~m}$ of altitude. The climate of the region is classified as humid subtropical (Cfa) with hot summer and mean annual temperature and rainfall of $17.4{ }^{\circ} \mathrm{C}$ and 1,533 mm, respectively. Pinot Noir, grafted on 1103 Paulsen, cultivated with 4, 9 and 16 years of planting on Ultisol Xerults (EMBRAPA 2018), distributed at spacing of $2.5 \mathrm{~m}$ between rows and $1.3 \mathrm{~m}$ between plants, supported by a trellis system at three positions: planting row (CPL), wheel tracks (WT) and between wheel tracks (BWT), in the layers of 0.0-0.10, 0.10-0.20, 0.20-0.30, 0.30-0.40, 0.400.50 and 0.50-0.60 m. Soil samples were also collected in a native grassland of the region (umbric Dystrophic Red Argisol), as a reference. The physical characteristics of the soils in the evaluated areas are described in Table 1. 
Table 1. Particle-size distribution, particle density (PD) in the $0.00-0.10,0.10-0.20,0.20-0.35,0.30-0.40$, and $0.40-0.60 \mathrm{~m}$ layers, of the native grassland and the vineyards with 4,9 and 16 years of management after planting the vines.

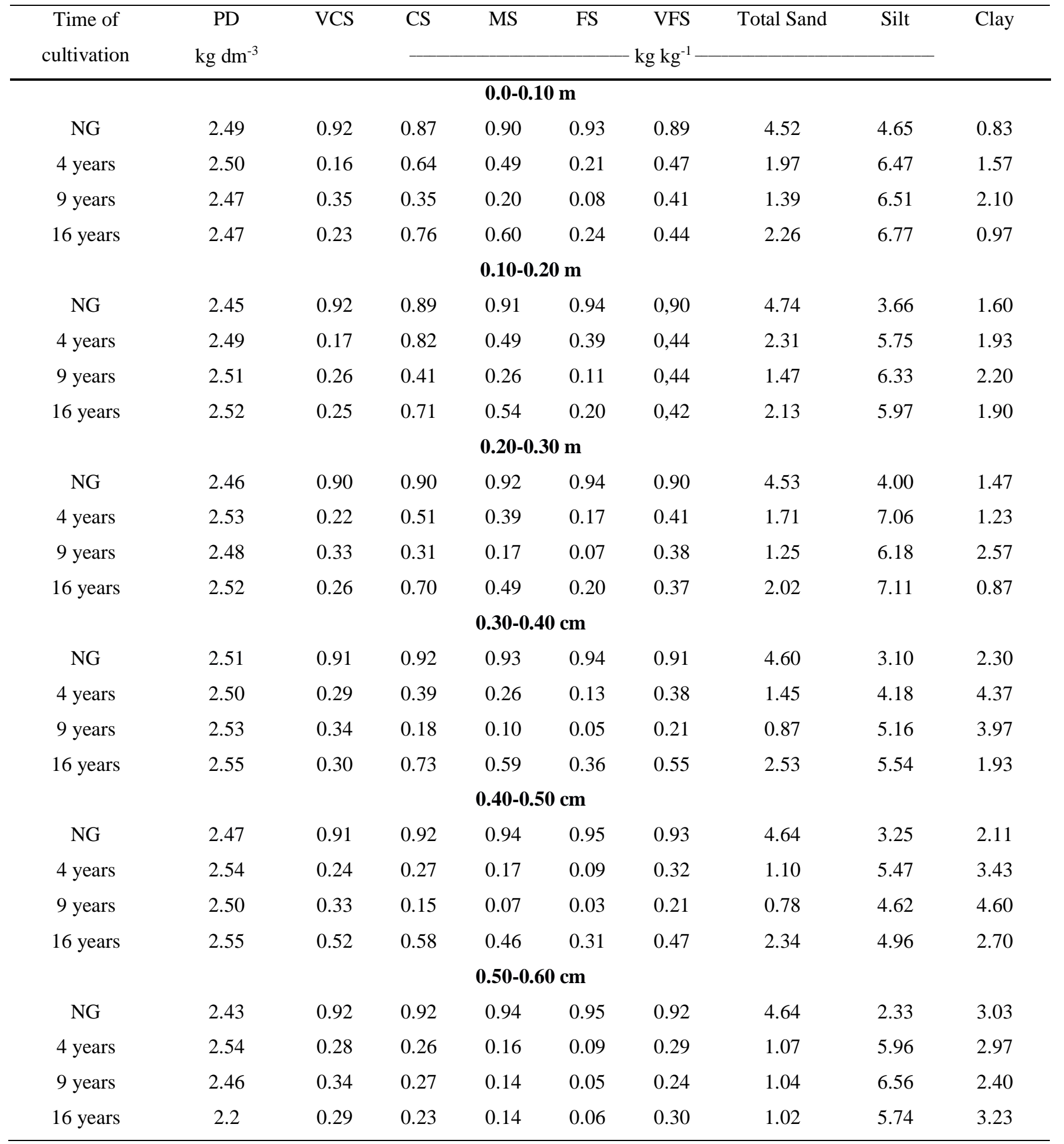

Particle size classification by the USDA: VCS (very coarse sand) = particles between 2.0 and $1.0 \mathrm{~mm}$; CS (coarse sand) = particles between 1.0 and $0.5 \mathrm{~mm}$; MS (medium sand) = particles between 0.5 and $0.25 \mathrm{~mm}$; FS (fine sand) = particles between 0.25 and $0.105 \mathrm{~mm}$; VFS $($ very fine sand $)=$ particles between 0.105 and $0.053 \mathrm{~mm}$; total sand $=2.0-0.053 \mathrm{~mm}$; silt $=0.05-0.002 \mathrm{~mm}$; clay <0.002 mm. Source: Authors.

Undisturbed soil samples were collected with a $102.10 \mathrm{~cm}^{3}$ volumetric ring. These samples were subjected to saturation for 48 hours on a tray with water up to two thirds the ring height to evaluate soil attributes according to the methodologies described by Embrapa (2011). After the saturation period, the samples were weighed and placed on a tension 
table at $6 \mathrm{kPa}$. When the samples no longer lost water, they were removed from the table tension, weighed and dried in an oven at $105^{\circ} \mathrm{C}$ until constant weight.

The difference between the weights of the samples at saturation and after application of a $6 \mathrm{kPa}$ suction on the table tension was used to determine soil macroporosity (Ma) (pores with diameter larger than $0.05 \mathrm{~mm}$ ), whereas the difference between the weights of the samples after $6 \mathrm{kPa}$ suction application and after drying in oven at $105{ }^{\circ} \mathrm{C}$ was used to determine soil microporosity (Mi) (pores with diameters between 0.05 and $0.0002 \mathrm{~mm}$ ). Soil total porosity (TP) was obtained by the sum of these two attributes. Soil bulk density (BD) was determined by the ratio between the mass of soil dried in oven at $105^{\circ} \mathrm{C}$ and ring volume.

Organic matter content $(\mathrm{OM})$ was estimated based on soil organic carbon content (OC), determined by the modified Walkley-Black wet combustion method, described by Tedesco et al. (1995). For that, $0.5 \mathrm{~g}$ of soil were weighed and transferred to a $500-\mathrm{mL}$ Erlenmeyer flask and then mixed with $10 \mathrm{~mL}$ of $1 \mathrm{~N} \mathrm{~K}_{2} \mathrm{Cr}_{2} \mathrm{O}_{7}$ and $20 \mathrm{~mL}$ of concentrated $\mathrm{H}_{2} \mathrm{SO}_{4}$. The solution was shaken for 1 minute and left to rest for 30 minutes. Then, $200 \mathrm{~mL}$ of distilled water, $10 \mathrm{~mL}$ of concentrated $\mathrm{H}_{3} \mathrm{PO}_{4}$ and $1 \mathrm{~mL}$ of diphenylamine indicator were added and the solution was titrated using $0.5 \mathrm{~N}(\mathrm{NH} 4)_{2} \mathrm{FeSO}_{4} \cdot 10 \mathrm{H}_{2} \mathrm{O}$.

Soil organic carbon stocks were determined using the equivalent soil mass method proposed by Ellert et al. (1995), according to the following equation:

\section{Msoil = BD.T.10000 $\mathrm{m}^{2} \mathrm{ha}^{-1}$}

Where: Msoil = soil mass per unit area $\left(\mathrm{Mg} \mathrm{ha}^{-1}\right) ; \mathrm{BD}=$ bulk density $\left(\mathrm{Mg} \mathrm{m}^{-3}\right) ; \mathrm{T}=$ thickness of the sampled layer (m).

Since soil compaction leads to the collection of a sample smaller than required for the study, soil thickness was corrected using the equations proposed by Conceição (2006).

$$
\text { Tadd/sub }=\left((\text { Mref-Mtreat }) \times 0.0001 \text { ha }^{-2}\right) / \text { BD }
$$

Where: Tadd/sub $=$ soil thickness to be added to or subtracted from a certain layer of the treatment to attain the corresponding value of the equivalent mass $(\mathrm{m})$; Mref = equivalent soil mass of the respective layer in the reference area $\left(\mathrm{Mg} \mathrm{ha}^{-1}\right)$; Mtreat = equivalent soil mass of the respective layer of the treatment $\left(\mathrm{Mg} \mathrm{ha}^{-1}\right)$; $\mathrm{BD}=$ bulk density $\left(\mathrm{Mg} \mathrm{m}^{-3}\right)$.

$$
\text { Tc }=\mathbf{T}+\mathbf{T a d d} / \mathrm{sub}
$$

Where: $\mathrm{Tc}=$ corrected thickness $(\mathrm{cm}) ; \mathrm{T}=$ thickness $(\mathrm{cm})$; Tadd/sub $=$ soil thickness to be added to or subtracted from a certain layer of the treatment to attain the corresponding value of the equivalent mass (m).

Carbon stocks were estimated considering the correction of the sampled layer thickness, according to the equivalent soil mass, based on the equation described by Fernandes et al. (2009):

$$
\text { OCS }=(\text { OC.BD.Tc }) / 10
$$

OCS $=$ organic $\mathrm{C}$ stock at certain depth $\left(\mathrm{Mg} \mathrm{ha}^{-1}\right) ; \mathrm{OC}=$ total organic $\mathrm{C}$ content at the sampled depth $\left(\mathrm{g} \mathrm{kg}^{-1}\right) ; \mathrm{BD}=$ bulk density $(\mathrm{g} \mathrm{cm}-3) ; \mathrm{Tc}=$ corrected thickness of the considered layer $(\mathrm{cm})$. 
The experimental design was randomized blocks, analyzed as split-split plots, considering the reference area and the three years of management after planting the vines as main plots (NG, 4, 9 and 16 years), three sampling sites as subplots (BWT - between wheel tracks, WT - in the wheel tracks and CPL - planting row) and six layers as sub-subplots (0-10, 10-20, 20-30, 30-40, 40-50 and 50-60 cm), in three replicates. All attributes were subjected to analysis of variance and means were compared by Tukey test at 0.05 probability level.

\section{Results}

Based on the results for the analysis of soil structure, it is possible to note that, in general, there was a significant statistical difference in macroporosity (Ma), microporosity (Mi), total porosity (TP) and bulk density (BD), in relation to the three cultivation periods after years of planting the vines (4, 9 and 16 years), the sampling sites between wheel tracks (BWT), wheel tracks (WT) and planting row (LP), and depth (Table 2).

In all studied sites (cultivation periods and sampling position), there were higher values of $\mathrm{Mi}\left(0.25\right.$ to $\left.0.75 \mathrm{~m}^{3} \mathrm{~m}^{-3}\right)$, compared to Ma $\left(0.05\right.$ and $\left.0.16 \mathrm{~m}^{3} \mathrm{~m}^{-3}\right)$. The area with 4 years of cultivation showed higher values of Mi at the position WT, especially in the first $30 \mathrm{~cm}$ of soil, which may have occurred because this area is still under effect of the soil turning, performed during tillage to plant the seedlings.

The values of $\mathrm{Mi}$ in the area with 9 years of cultivation were higher at the positions BWT and CPL, from $40 \mathrm{~cm}$, whereas the area with 16 years of cultivation did not show significant statistical difference. This may have occurred because, over the years, the effect of soil compaction is more accentuated on the subsurface layers, due to the low content of organic matter, reduced presence of roots and microorganisms capable of favoring aggregation and formation of biopores, as well as higher contents of clay fractions and finer sand fractions, which clog macropores in subsurface layers.

Bulk density (BD) values ranged from 1.15 to $1.69 \mathrm{Mg} \mathrm{m}^{-3}$, which are higher than that considered as critical $(1.2 \mathrm{Mg}$ $\mathrm{m}^{-3}$ ) for structural degradation (Araujo-Junior et al., 2011). The native grassland showed higher values of bulk density, because there is no management aiming to change soil structure, such as ploughing, which allows for a natural bulk density, due to the rearrangement of mineral particles.

According to the results obtained for soil organic matter $(\mathrm{OM})$, there was significant statistical difference between all studied areas. The native grassland showed the highest values, between 2.97 and $2.37 \mathrm{~g} \mathrm{~kg}^{-1}$. In relation to the managed areas, the highest values were observed in the area with 9 years of management ( 1.70 to $2.90 \mathrm{~g} \mathrm{~kg}^{-1}$ ), followed by the areas with 4 and 16 years of cultivation, in which the values ranged from 1.30 to $2.73 \mathrm{~g} \mathrm{~kg}^{-1}$ and from 1.33 and $2.37 \mathrm{~g} \mathrm{~kg}^{-1}$, respectively. Lower values were found in the area with 16 years of cultivation because this area has been under intense chemical and mechanical control of cover plants in the vineyard rows and interrows over the years. It can be observed that there was a reduction in the organic matter content in subsurface, with highest values in the first $30 \mathrm{~cm}$, which is related to the supply of organic material from surface soil. 


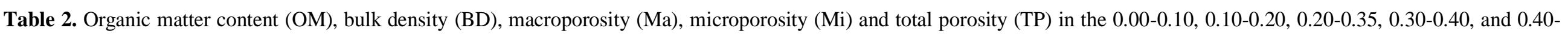

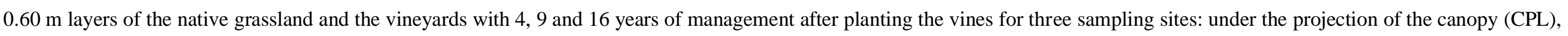
in the wheels tracks (WT), and between the wheel tracks (BWT).

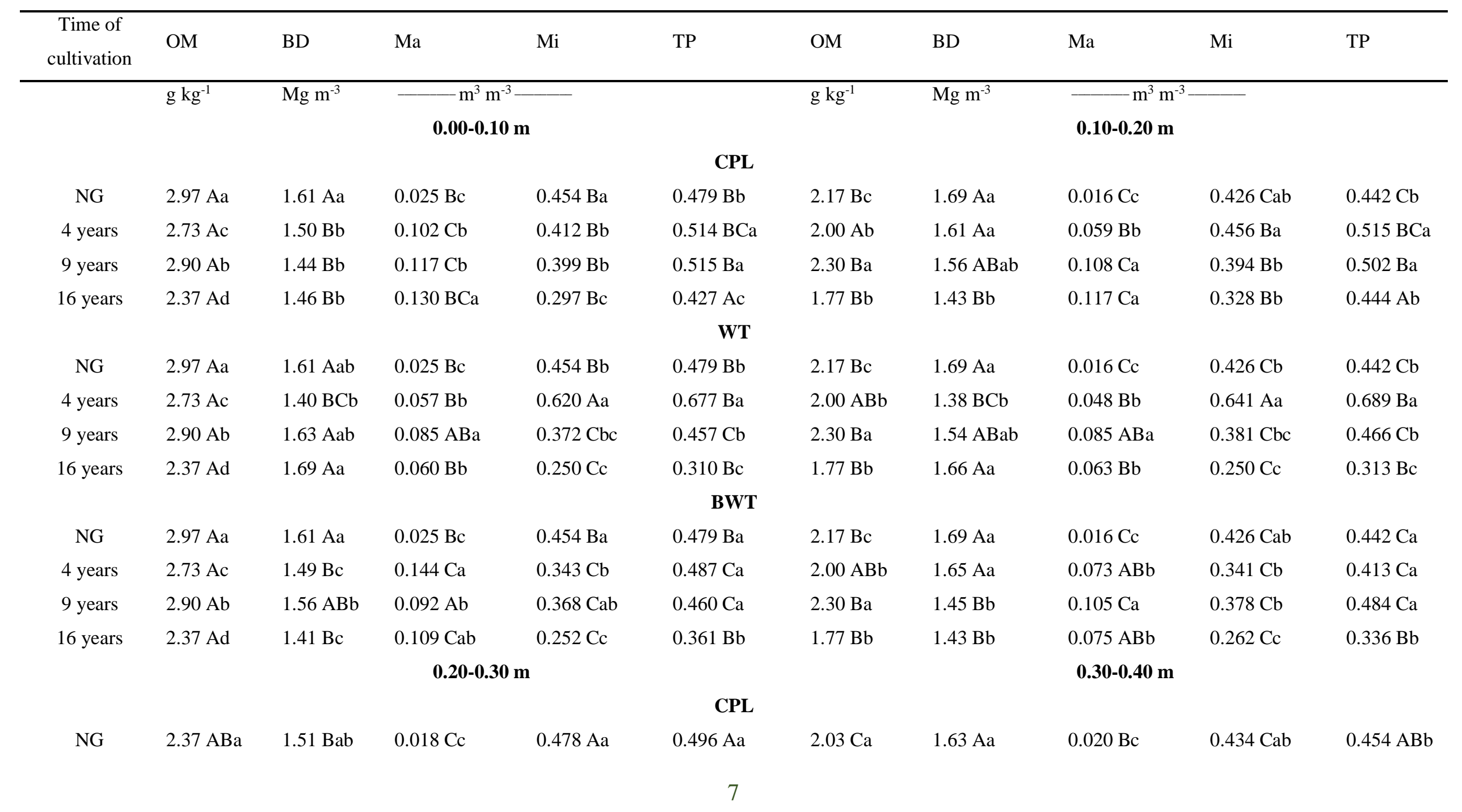


Research, Society and Development, v. 10, n. 3, e10610311840, 2021

(CC BY 4.0) | ISSN 2525-3409 | DOI: http://dx.doi.org/10.33448/rsd-v10i3.11840

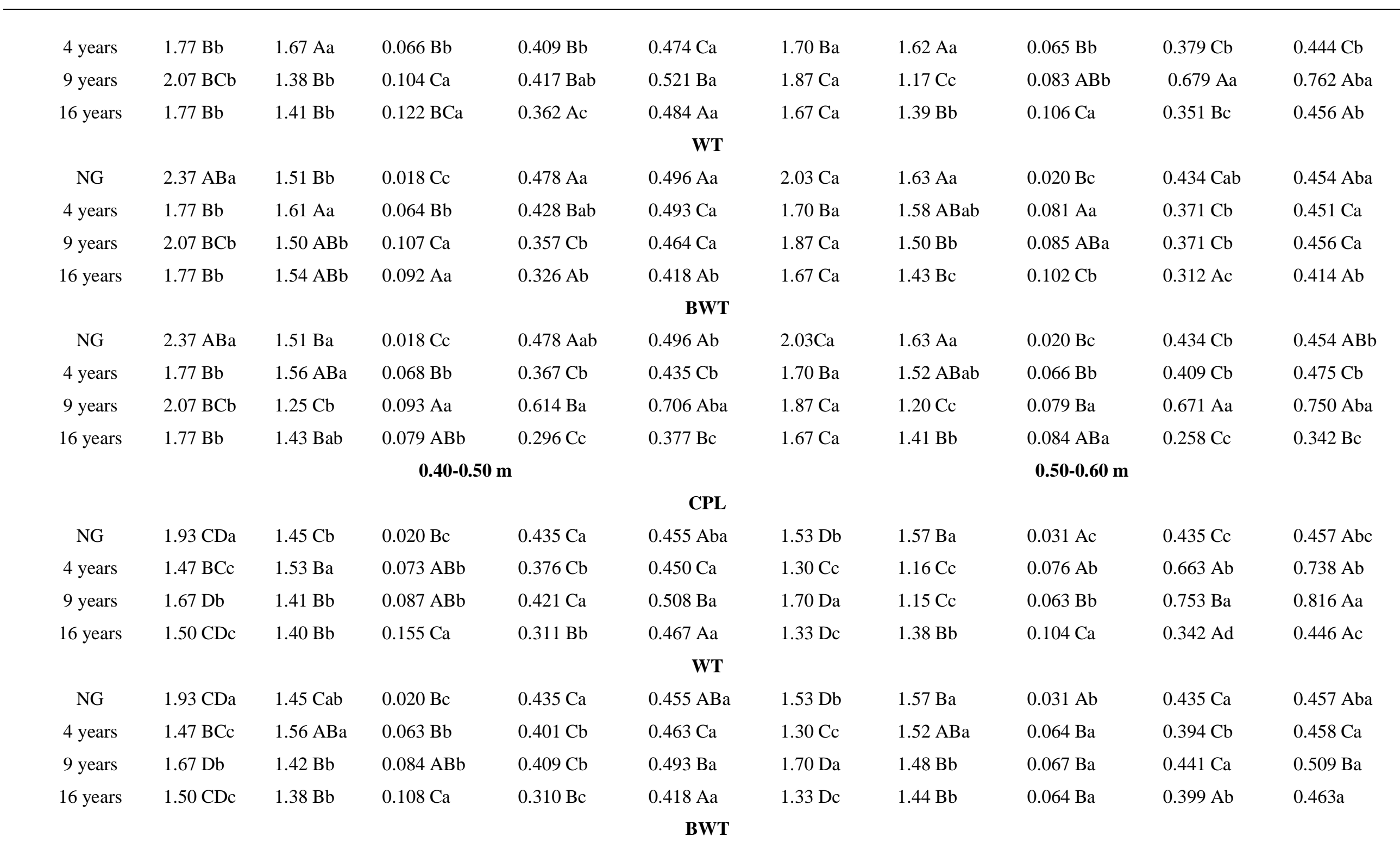


Research, Society and Development, v. 10, n. 3, e10610311840, 2021

(CC BY 4.0) | ISSN 2525-3409 | DOI: http://dx.doi.org/10.33448/rsd-v10i3.11840

\begin{tabular}{|c|c|c|c|c|c|c|c|c|c|c|}
\hline NG & $1.93 \mathrm{CDa}$ & $1.45 \mathrm{Ca}$ & $0.020 \mathrm{Bc}$ & $0.435 \mathrm{Cb}$ & $0.455 \mathrm{ABb}$ & $1.53 \mathrm{Db}$ & $1.57 \mathrm{Ba}$ & $0.031 \mathrm{Ac}$ & $0.435 \mathrm{Ca}$ & $0.457 \mathrm{ABa}$ \\
\hline 4 years & $1.47 \mathrm{BCc}$ & $1.48 \mathrm{BCa}$ & $0.057 \mathrm{Bb}$ & $0.393 \mathrm{Cc}$ & $0.450 \mathrm{Cb}$ & $1.30 \mathrm{Cc}$ & $1.48 \mathrm{BCb}$ & $0.066 \mathrm{Bb}$ & $0.396 \mathrm{Cb}$ & $0.461 \mathrm{Ca}$ \\
\hline 9 years & $1.67 \mathrm{Db}$ & $1.15 \mathrm{Cb}$ & $0.071 \mathrm{Ba}$ & $0.698 \mathrm{Aa}$ & $0.759 \mathrm{Aba}$ & $1.70 \mathrm{Da}$ & $1.49 \mathrm{Bb}$ & $0.072 \mathrm{Ba}$ & $0.409 \mathrm{Ca}$ & $0.481 \mathrm{Ca}$ \\
\hline 16 years & $1.50 \mathrm{CDc}$ & $1.44 \mathrm{Ba}$ & $0.072 \mathrm{ABa}$ & $0.287 \mathrm{Bd}$ & $0.359 \mathrm{Bc}$ & $1.33 \mathrm{Dc}$ & $1.45 \mathrm{Bb}$ & $0.099 \mathrm{Aa}$ & $0.312 \mathrm{Bb}$ & $0.411 \mathrm{Aa}$ \\
\hline
\end{tabular}

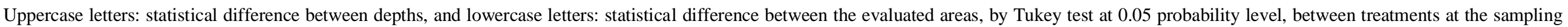
sites. Source: Authors. 
According to the organic carbon stocks in the soil (Figure 1), in general, there was significant statistical difference between the years of cultivation and the reference area, sampling sites and depth. The native grassland, due to the lack of change in its cover and in its use and management, showed the highest carbon stocks in the soil, $11.80 \mathrm{Mg} \mathrm{ha}^{-1}$. Regardless of the years of cultivation and sampling position, the highest carbon storage was found within the first $0.30 \mathrm{~m}$, with values ranging from 1.18 to $2.78 \mathrm{Mg} \mathrm{ha}^{-1}$.

Figure 1. Soil-stored carbon in the native grassland and in vineyards with 4, 9 and 16 years of management after planting the vines for three sampling sites: under the projection of the canopy (CPL), in the wheel tracks (WT), and between the wheels tracks (BWT). Uppercase letters: statistical difference between depths, and lowercase letters: statistical difference between the evaluated areas, by Tukey test at 0.05 probability level, between treatments at the sampling sites.
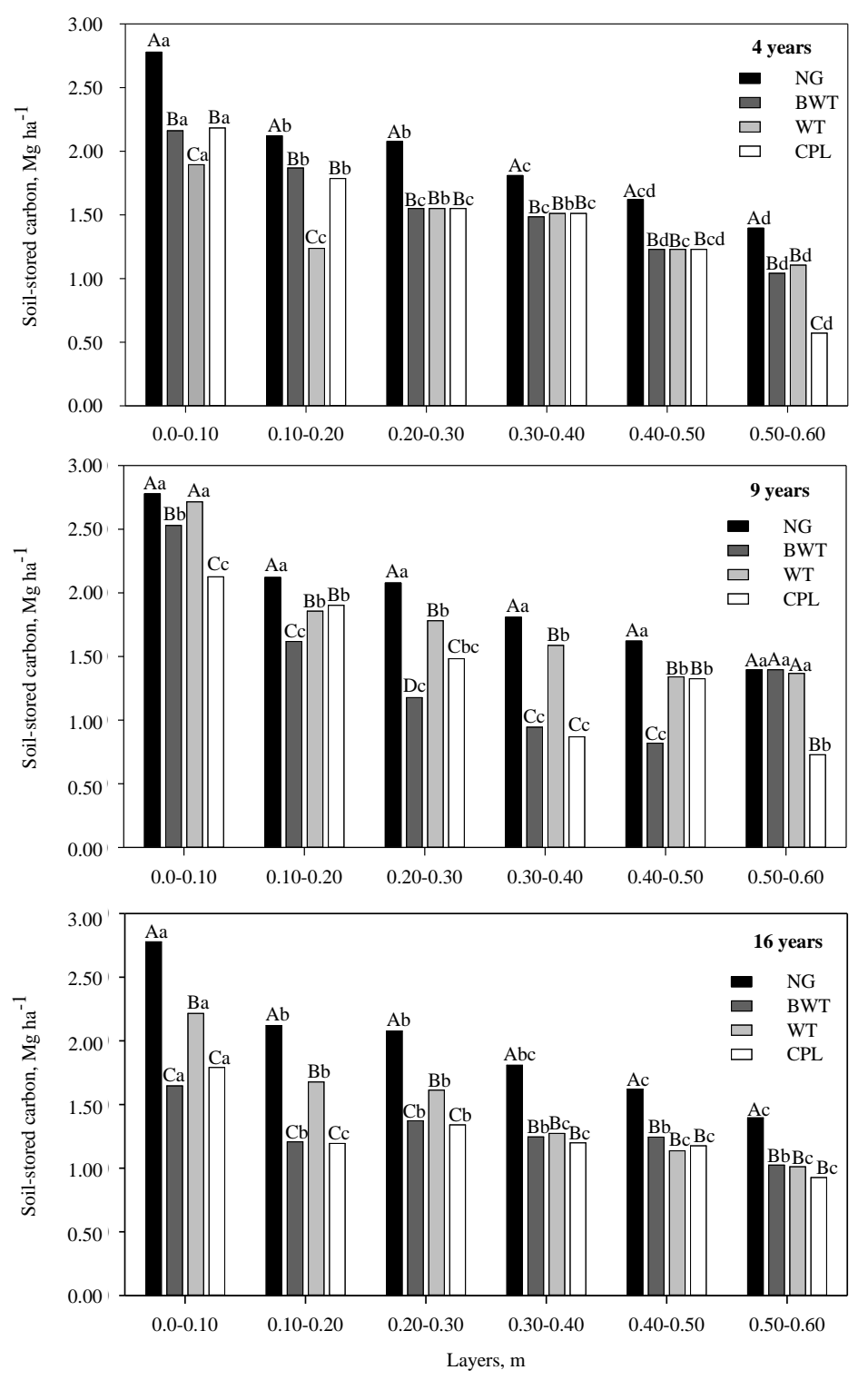

Source: Authors. 
Research, Society and Development, v. 10, n. 3, e10610311840, 2021

(CC BY 4.0) | ISSN 2525-3409 | DOI: http://dx.doi.org/10.33448/rsd-v10i3.11840

Considering the years of planting, the area with 9 years of cultivation had the highest mean value $\left(9.19 \mathrm{Mg} \mathrm{ha}^{-1}\right)$, followed by the areas with 4 and 16 years of management, with mean values of 8.90 and $9.10 \mathrm{Mg} \mathrm{ha}^{-1}$, respectively. Lower values in the area with 4 years were observed because this area is still affected by the turning performed during soil tillage, which led to accelerated oxidation of organic matter.

In relation to the sampling sites, the highest values were observed in the wheel tracks of the tractor (WT), with mean value of $9.37 \mathrm{Mg} \mathrm{ha}^{-1}$, followed by the positions between wheel tracks (BWT) and planting row (CPL), with mean values of 8.52 and $8.30 \mathrm{Mg} \mathrm{ha}^{-1}$, respectively. This can be attributed to the higher values of microporosity at this site, which favored the temporary mitigation of $\mathrm{C}$ among soil particles. However, with continuous movement of tractor wheels, the soil may lose its capacity for $\mathrm{C}$ storage and sequestration in its structure.

\section{Discussion}

Soil tillage is the activity with greatest influence on physical attributes because the application of dynamic loads by tractor wheels and agricultural implements on the soil produces stresses at the soil/tire and soil/implement interfaces in surface and subsurface, compacting the different layers of the soil (Wiermannn et al., 2000; Vieira \& Klein, 2007). According to Spera et al. (2004), the conversion of natural ecosystems to agricultural activities, completely aimed at commercial production, leads to changes in soil physical properties which are usually unfavorable to plant development.

Braida et al. (2010) observed that soil susceptibility to compaction can be altered by organic matter accumulation, but soil structure and its effects associated with water retention, cohesion and bulk density determine its magnitude.

According to Reichardt and Timm (2004) and Libardi (2005), medium-textured soils should have microporosity ranging from 60 to $70 \%$ and from 30 to $40 \%$ of the total porosity, respectively, in the first $30 \mathrm{~cm}$, which was not observed in the present study. In general, up to this depth the soil showed macroporosity between 7 and $30 \%$ of the total porosity and microporosity between 69 and $63 \%$ of the total porosity. This reflects the effects of soil compaction, regardless of use and years of management.

The results of soil bulk density were similar to others found at different sampling positions in medium-textured soils in the interrows of vineyards in Santa Catarina (Valois et al., 2014), and in other perennial crops such as coffee (Gontijo et al., 2008) and citrus (Santos et al., 2014) subjected to intense traffic of machines, in which the increase in bulk density resulted in reduction in the total volume of pores (TP). According to Araujo-Junior et al. (2011), this result can be attributed to the soil tillage systems. The values found were considered as critical for a good development of crops in the first $0.30 \mathrm{~m}$ of a mediumtextured soil (Durigan \& Timossi 2002; Reichert et al., 2003).

According to Rosa (2009), such alteration in soil structure leads to reduction in aeration and water infiltration in the soil, due to the decrease in macroporosity. On the other hand, the increase in microporosity favors the retention of the small volume of water which percolates in the soil profile. However, in some situations, this water is not necessarily available to plants because there are situations in which the diameter of these pores is greatly reduced and water may remain retained with very high energy, thus being unavailable to plants (Klein et al., 2009; Toigo 2010).

Higher values of OM in surface were observed because this layer has greater accumulation of material on soil surface, microorganisms and higher presence of roots of cover plants, especially in the native grassland and in the area with 9 years of management, due to the roots of the vines, which contributed to the cycling of nutrients, aggregation and water storage (Alcântara et al. 2000, Boer et al. 2007).

The conversion of the type of cover, with turning of the soil to plant grape seedlings, caused alteration in $\mathrm{C}$ stock, evidenced by the values found in the native grassland and the areas with different soil uses and managements. Similar results 
Research, Society and Development, v. 10, n. 3, e10610311840, 2021

(CC BY 4.0) | ISSN 2525-3409 | DOI: http://dx.doi.org/10.33448/rsd-v10i3.11840

were found by Stürmer et al. (2011), evaluating C stock dynamics in deforested and revegetated areas in Southern Brazil. According to the literature, substituting native pasture and natural forests for agricultural systems of cultivation may lead to a reduction in soil $\mathrm{C}$ content, primarily in response to the acceleration in the decomposition rate caused by the cultivation of the soil and greater aeration and physical exposure of OM to decomposer microorganisms (Zinn et al., 2005).

Soil C stock can be altered with higher or lower intensity, depending on the agricultural system adopted, and is one of the most sensitive attributes to the transformations triggered by management. Inadequate management practices may lead to rapid decline in these stocks, contributing to the increase in carbon dioxide $\left(\mathrm{CO}_{2}\right)$ emissions to the atmosphere (Freixo et al., 2002).

It is possible to observe that the soil under the wheel tracks showed the highest $\mathrm{C}$ stocks, mainly in the areas with 9 and 16 years of cultivation. This can be attributed to the fact that, with the modification in soil structure, caused by compaction, the organic matter was closely related to the micropores of the soil.

\section{Conclusion}

Soil management caused alterations in soil structure and organic matter content, especially in the first $30 \mathrm{~cm}$, regardless of the area studied;

Highest bulk density values were observed in the tractor wheel tracks, followed by the planting row and between wheel tracks;

Alteration in soil cover to plant the vineyard led to a reduction in the carbon stock, compared to the native grassland;

Carbon stocks were heterogeneous in the vineyard interrows at the sites WT, BWT and CPL;

The area with 4 years showed higher carbon stocks between the wheel tracks, whereas the areas with 9 and 16 years showed higher values in the wheel tracks of the tractor.

\section{Agradecimentos}

Aos colegas e servidores da Universidade Federal do Rio Grande do Sul pelas contribuições para com este estudo e aos órgãos de fomento CAPES e CNPq pelo auxílio financeiro.

\section{References}

Alcântara, F. A., Furtini neto, A. E., Paula, M. B., Mesquita, H. A., \& Muniz, J. A. (2000). Adubação verde na recuperação da fertilidade de um Latossolo Vermelho-escuro degradado. Pesquisa Agropecuária Brasileira, 35, 277-288. http://dx.doi.org/10.1590/S0100-204X2000000200006

Araujo-Junior, C. F., Dias Junior, M. de S., Guimaraes, P. T. G. \& Alcantara, E. N. (2011). Capacidade de suporte de carga e umidade crítica de um Latossolo induzida por diferentes manejos. Revista Brasileira de Ciência do Solo, 35, 115-131. http://dx.doi.org/10.1590/S0100-06832011000100011.

Bayer, C. \& Mielniczuk, J. (2008). Dinâmica da matéria orgânica. In: Fundamentos da matéria orgânica do solo: ecossistemas tropicais e subtropicais. (Eds. Santos, G. de A., Silva, L. S., Canellas, L. P. \& Camargo, F. de O.). (2a ed.), 2, 7-18. Metrópole.

Bernoux, M. Cerri, C. C., Volkoff, B., Carvalho, M. D. S., Feller, C., Cerri, C. E. P., Eschenbrenner, V., Piccolo, M. C., \& Feigl, B. (2005). Gases do Efeito Estufa e Estoques de Carbono nos Solos: Inventário do Brasil. Cadernos de Ciência \& Tecnologia, 22, 235-246

Boer, C. A., Assis, R. L. de, Silva, G. P., Braz, A. J. B. P., Barroso, A. L. de L., Cargnelutti Filho, A., \& Pires, F. R. (2007). Ciclagem de nutrientes por plantas de cobertura na entressafra em um solo de Cerrado. Pesquisa Agropecuária Brasileira, 42, 1269- 1276. http://dx.doi.org/10.1590/S0100$204 X 2007000900008$.

Braida, J. A., Reichert, J. M., Reinert, D. J. \& Veiga, M. (2010). Teor de carbono orgânico e a susceptibilidade à compactação de um Nitossolo e Argissolo. Revista Brasileira de Engenharia Agrícola e Ambiental, 14, 131-139. http://dx.doi.org/10.1590/S1415-43662010000200003

Brown, S., Anderson, J. M., Woomer, P. L., Swift, M. J. \& Barrios, E. (1994). Soil biological processes in tropical ecosystems. In: The biological management of tropical soil fertility. (Eds. Woomer, P. L. \& Swift, M. J.). 15-46. John Wiley \& Sons, Chichester. 
CONCEIÇÃO, P.C. (2006). Agregação e proteção física da matéria orgânica em dois solos do sul do Brasil. Porto Alegre, Universidade Federal do Rio Grande do Sul, 138p. (Tese de Doutorado)

Diekow, J., Mielniczuk, J., Knicker, H., Bayer, C., Dick, D.P. \& Kögel-Knabner, I., (2005). Soil C and N stocks as affected by cropping systems and nitrogen fertilization in a Southern Brazil Acrisol managed under no-tillage for 17 years. Soil and Tillage Research. 81, 87-95. https://doi.org/10.1016/j.still.2004.05.003.

Durigan, J. C. \& Timossi, P. C. (2002). Manejo de plantas daninhas em pomares cítricos. (Boletim Citrícola, n. 22), 53, EECB Bebedouro.

Ellert, B. H., \& Bettany, J. R. (1995). Calculation of organic matter and nutrients stored in soil under contrasting management regimes. Canadian Journal of Soil Science, 75, 529-538. https://doi.org/10.4141/cjss95-075.

EMBRAPA. 2011. Manual de métodos de análises de solos. (2a ed.), 230p. Embrapa Solos.

Fernandes, F. A. \& Fernandes, A. H. B. M. 2009. Cálculo dos estoques de carbono do solo sob diferentes condições de manejo. 4 p. Embrapa, Pantanal Corumbá.

Freixo, A. A., Machado, P. L. O. A., Guimarães, C. M., Silva, C. A., \& Fadigas, F. S. (2002). Estoques de carbono e nitrogênio e distribuição de frações orgânicas de Latossolo do Cerrado sob diferentes sistemas de cultivo. Revista Brasileira de Ciência do Solo, 26, 425-434. http://dx.doi.org/10.1590/S010006832002000200016 .

Gontijo, I.; Dias Junior, M. S.; Guimarães, P. T. G. \& Araujo-Junior, C. F. (2008). Atributos físico-hídricos de um Latossolo de cerrado em diferentes posições de amostragem na lavoura cafeeira. Revista Brasileira de Ciência do Solo, 32, 2227-2234. http://dx.doi.org/10.1590/S0100-06832008000600002.

Klein, V. A., Bassegio, M. Madalosso, T. (2009). Indicadores da qualidade física de um Latossolo Vermelho distrófico típico sob plantio direto escarificado. Ciência Rural, 39, 2475-2481. http://dx.doi.org/10.1590/S0103-84782009005000225.

Libardi, P. L. 2005. Dinâmica da água no solo. 335p. EDUSP, São Paulo

Novais, R. F., Smyth, T. J. \& Nunes, F. N. (2007). Fertilidade do Solo. 1017p. Sociedade Brasileira de Ciência do Solo, Viçosa.

Rangel, O. J. P. \& Silva, C. A. (2007). Estoques de carbono e nitrogênio e frações orgânicas de Latossolo submetido a diferentes sistemas de uso e manejo. Revista Brasileira de Ciência do Solo, 31, 1609-1623. http://dx.doi.org/10.1590/S0100-06832007000600037

Reichardt, K. \& Timm, L. C. (2004). Solo, Planta e Atmosfera: conceitos, processos e aplicações. 478p. Editora Manole.

Reichert, J. M., Reinert, D. J. \& Braida, J. A. (2003). Qualidade dos solos e sustentabilidade de sistemas agrícolas. Ciência \& Ambiente. 14, 29-48.

Rosa, R., Sano, E. E. \& Rosendo, J. dos S. de. (2014). Estoque de carbono em solos sob pastagens cultivadas na bacia hidrográfica do Rio Paranaíba. Sociedade \& Natureza. 26, 333-351. https://doi.org/10.1590/1982-451320140210

Rosa Filho, G., Carvalho, M. de P. e, Andreotti, M., Montanari, R., Binotti, F. F. da S. \& Gioia, M. T. (2009). Variabilidade da produtividade da soja em função de atributos físicos de um Latossolo Vermelho Distroférrico sob plantio direto. Revista Brasileira de Ciência do solo, 33, 283-293. http://dx.doi.org/10.1590/S0100-06832009000200006.

Santos, C. V., Levien, R., Schwarz, S. F., Mazurana, M., Petry, H. B., Zulpo, L. \& Fink, J. A. (2014). Physical-hydraulic properties of a sandy loam typic paleudalf soil under organic cultivation of 'montenegrina' mandarin (Citrus deliciosa Tenore). Revista Brasileira de Ciência do Solo. 38, $1882-1889$. http://dx.doi.org/10.1590/S0100-06832014000600023

Silva, I. R. \& Medonça, E. S. (2007). Matéria orgânica do solo. In: Fertilidade do solo. (Eds. Novais, R. F., Smyth, T. J. \& Nunes, F. N.). 275- 375. Sociedade Brasileira de Ciência do Solo, Viçosa.

Silva, R. F., Aquino, A. M. de; Mercante, F. M. \& Guimaraes, M. de F. 2006. Macrofauna invertebrada do solo sob diferentes sistemas de produção em Latossolo da Região do Cerrado. Pesquisa Agropecuária Brasileira, 41, 697-704. http://dx.doi.org/10.1590/S0100-204X2006000400022.

Sleutel, S., De Neve, S. \& Hofman G. (2006). Estimates of carbon stock changes in Belgian cropland. Soil Use and Management, 19, 166-171. http://dx.doi.org/10.1111/j.1475-2743.2003.tb00299.x

Spera, S.T., Santos, H.P., Tomm, G.O. \& Fontaneli, R.S. (2004). Avaliações de alguns atributos físicos de solo em sistemas de produção de grãos, envolvendo pastagens sob plantio direto. Revista Científica Rural, 9, 23-31.

Stürmer, S. L. K., Rossato, O. B., Copetti, A. C. C., Santos, D. R., Calegari, A. \& Brum, B. (2011). Variações nos teores de carbono orgânico em função do desmatamento e revegetação natural do solo. Ciência. Florestal, 21, 241-250. http://dx.doi.org/10.5902/198050983228.

Tedesco, M. J., Gianello, C., Bissani, C. A., Bohnen, H. \& Wolkweiss, S. J. (1995). Análise de solo, plantas e outros materiais. (2a ed.), 174p. Universidade Federal do Rio Grande do Sul, Porto Alegre.

Toigo, S. (2010). Remediação mecânica e biológica da compactação inicial de um Nitossolo Vermelho cultivado com trigo. Dissertação (Mestrado) 80f. Universidade Tecnológica Federal do Paraná. Programa de Pós-Graduação em Agronomia. Pato Branco.

Valois, C. M. de, Comin, J. J., Veiga, M. da, Brunetto, G., Fayad, J. A., Bauer, F. C., Loss, A., Moraes, M. P. de, \& Lazzari, C. J. R. (2014). Physical attributes of a Haplic Cambisol in vineyards subjected to different traffic intensities. Revista Brasileira de Ciência do Solo, 38, 1256-1267. http://dx.doi.org/10.1590/S0100-06832014000400022. 
Research, Society and Development, v. 10, n. 3, e10610311840, 2021

(CC BY 4.0) | ISSN 2525-3409 | DOI: http://dx.doi.org/10.33448/rsd-v10i3.11840

Viana, M. C. M., Freire, F. M., Alvarenga, R. C., Queiroz D. S., Paula, M. H. C., Rezende I. F. (2016). Monitoramento do estoque de carbono no solo no sistema de Integração Lavoura-Pecuária-Floresta em área de cerrado de Minas Gerais. In: Congresso Nacional de Milho E Sorgo, 31 . Associação Brasileira de Milho e Sorgo, Bento Gonçalves.

Vieira, M. L. \& Klein, V. A. (2007). Propriedades físico-hídricas de um Latossolo Vermelho submetido a diferentes temas de manejo. Revista Brasileira de Ciência do Solo, 31, 1271-1280. http://dx.doi.org/10.1590/S0100-06832007000600006.

Wiermann C., Werner D., Horn R., Rostek J. \& Werner B., (2000). Stress/strain processes in a structured silty loam Luvisol under different tillage treatments in Germany. Soil \& Tillage Research, 53, 117-128. https://doi.org/10.1016/S0167-1987(99)00090-2

Zinn, Y. L., Lal, R. \& Resck, D. V. S. (2005). Changes in soil organic carbon stocks under agriculture in Brazil. Soil \& Tillage Research, 84, 28-40. https://doi.org/10.1016/j.still.2004.08.007 